\title{
Success factors when implementing innovation teams
}

\author{
Mikael J. Johnsson* \\ Blekinge Institute of Technology, 37179 Karlskrona, Sweden. \\ E-mail: mikael.johnsson@bth.se,mikael.j.johnsson@gmail.com
}

\section{Ewa Svensson}

Crearum AB, Gjutargatan 1c, 58273 Linköping, Sweden.

E-mail: ewa.svensson@crearum.se

\section{Kristina Swenningsson}

Crearum AB, Gjutargatan 1c, 58273 Linköping, Sweden.

E-mail: kristina.swenningsson@crearum.se

* Corresponding author

\begin{abstract}
This research explores the success factors of the research-based process for creating high-performing innovation teams, called the CIT-process. This paper is part of a study through which problems in the implementation of high-performing innovation teams were identified (Johnsson et al., 2019) when being used by innovation management practitioners (practitioners). The CITprocess is a five-step process prior to the innovation process. Before organizations were involved, practitioners at an innovation management firm were educated in the CIT-process and evaluated. Three innovation teams were created by the practitioners, conducting real innovation projects, facilitated by the practitioners. Data were collected through filed notes and interviews with participants and the practitioners. Three main themes appeared as key success factors: knowledge adoption, knowledge transition and knowledge transfer. Limitations are highlighted and future research is suggested.
\end{abstract}

Keywords: innovation management; innovation team; innovation group; multidisciplinary; $\mathrm{x}$-functional; group development.

\section{Problem}

Recently, Johnsson (2017b) developed a methodology for creating innovation teams, the CIT-process, which helps avoid group-related problems. The process is demonstrated in the following section. As teams increase job satisfaction, reduce job stress and time pressure (e.g., Cordero et al., 1998) and reach the market faster (Highsmith, 2009), the purpose of the new approach was to diminish well-known issues in the creation of innovation teams, such as conflicts occurring in new groups conduction innovation work 
This paper was presented at The ISPIM Innovation Conference - Innovating Our Common Future, Berlin, Germany on 7-10 June 2020.

Event Proceedings: LUT Scientific and Expertise Publications: ISBN 978-952-335-467-8

(e.g., Kristiansen and Bloch-Poulsen, 2010) and group dynamic problems in general (e.g., Wheelan, 2013), and to support organizations in matching the ever-increasing speed of new products and services being launched on the market (e.g., Chen et al, 2010).

This paper is part of a prior study which identified problems in the implementation of highperforming innovation teams (Johnsson et al., 2019), which originate from the need of studying the CIT-process when being used by practitioners, for example, consultants in innovation management, to support organizations in creating innovation teams. For this reason, the current study aims to explore factors that contribute to the success of practitioners using this process.

\section{Current understanding}

Processes and knowledge regarding innovation teams have been developed for a long time (Farris, 1972; Im et al., 2013; McDonough, 2000; McGreevy, 2006; Neuman et al., 1999; Pearce \& Ensley; 2004; West, et al., 2004; Zuidema \& Kleiner, 1994). However, in contrast to prior research regarding the creation of innovation teams, Johnsson provides, through the CIT-process, hands-on advice comprising five steps, summarized in the following.

First, ensure the commitment of top management and team sponsor. Johnsson stresses this step as crucial because management sets the direction of innovation work. With no clear direction based on a company strategy, the innovation work may drift away from the business model.

Second, identify an innovation team convener (convener), who encourages common leadership as a team. Unlike a project manager, a convener encourages common leadership, through which the team members act as one unit. The convener keeps the agenda up to date and acts as the innovation team's communication channel to management and the team sponsor.

Third, introduce the convener to the processes of innovation management and group dynamics. If the convener is unfamiliar with the group development process, structured innovation work or the CIT-process itself, he or she should be introduced to the upcoming work, preferably by an innovation facilitator. This also applies to inexperienced managers and team sponsors. This step is significant because innovation is highly complex work; it spans from the CIT-process to market launch and value creation (Johnsson, 2018), meaning that the innovation team is dependent on resources and support through a range of activities and decisions. The group dynamic process is well established (e.g., Tuckmann and Jensen, 1977; Whelan, 2013), in which a group develops into a team through several phases, known as 'forming-storming-norming-performing'. The storming phase is exceptionally difficult because the team members tend to challenge not only the leader but also each other and the project as such, which drains energy and resources. Therefore, it is important to educate the convener and the entire innovation team so as to ease the recognition of potential upcoming problems.

Fourth, the convener gathers, preferable, four to six team members, with a minimum of three and maximum of seven members, of diverse functionalities who are key persons within their area of competence. These individuals should also feel positively toward multifunctional work and be proud of the company/organization they work for, and they should be motivated to contribute to the development of new products/services.

Fifth is the kick-off, the official start of the innovation project, first by establishing the norms of the innovation teams and then by setting the goal of the project. At the kick-off, all prior steps are repeated to align all team members with the same mindset. The CIT- 
process is conducted by management, the sponsor and the convener, with the support of an innovation facilitator if the organization is inexperienced in creating innovation teams.

In prior studies of the CIT-process, the focus has been on identifying factors that both enable the innovation team's work (Johnsson, 2017a) and are considered most important in ongoing innovation projects (Johnsson, 2016a, 2016b). Further, Johnsson (2018) has observed that an innovation facilitator is significant in creating innovation teams if the organization is inexperienced in such work. Despite prior research on the CIT-process, little is known about the success factors of practitioners using this process to support organizations in creating innovation teams. This research aims to explore these factors.

\section{Research question}

What success factors, if any, occur when practitioners use the CIT-process to support an organization in creating innovation teams?

\section{Research design}

This research was conducted in two steps, spanning from the pre-phase to the first steps in the ideation phase. In the first step, two consultants (practitioners) were identified and educated on the CIT-process at a consultancy firm, to act as innovation facilitators in accordance with Johnsson (2018). The practitioners were chosen because they were innovation management professionals certified by Innovationsledarna, which is associated with the International Society for Professional Innovation Management (ISPIM). In their profession, the practitioners have been involved in developing the innovation management ISO standard, ISO 56002. In the process of evaluating the practitioners' innovation-related skills, experience and knowledge, the practitioners were orally interviewed, and they answered a statement-based questionnaire. The interviews lasted about 40 minutes and were audio recorded. Relevant sections were transcribed. In the interviews, the practitioners answered questions such as the following:

- What experience do you have in advising innovation projects?

- What experience do you have in practical innovation work?

- What experience do you have on the process of innovation and group dynamics?

- Do you understand your role as an innovation facilitator?

The questionnaire consisted of 40 statements, based on Johnsson (2018), through which the practitioners assessed their abilities, for example:

- I have the ability to give concrete advice.

- I have the ability to steer back innovation teams that lose focus.

- I am available for support when the innovation team needs me.

- I assure the innovation team that uncertainty is OK.

- I create confidence in innovation teams to do things that innovation teams don't normally do.

- I challenge the innovation team if necessary. 
This paper was presented at The ISPIM Innovation Conference - Innovating Our Common Future, Berlin, Germany on 7-10 June 2020.

Event Proceedings: LUT Scientific and Expertise Publications: ISBN 978-952-335-467-8

- I have good coaching skills.

- I encourage the innovation team to push their boundaries.

- I facilitate the innovation team through the convening person.

- I have a good knowledge of the innovation process.

In the second step, with support by the practitioner, three innovation teams (Teams A-C) were created out of six organizations to conduct a real innovation project, that is, no fictive simulation. Team A consisted of four individuals and was created at one of the participating organizations. Team B was based on two organizations and consisted of 14 individuals. Finally, three organizations created one interorganizational innovation team: Team C, consisting of six individuals.

As the practitioners used the CIT-process, data were collected through recurrent reflective conversations with the practitioners and documented as filed notes, focusing on success factors as the work progressed and on whether the practitioners felt that they were in control. Furthermore, data were collected through transcribed, semistructured, in-depth interviews with the practitioners and the conveners from all innovation teams, which were audio recorded, approximately one month into the ongoing innovation projects. In the interviews, which lasted about forty minutes, the respondents were explicitly asked, 'What success factors have you noticed as the innovation team emerges?' and 'Do you see the innovation team as a team?' The interviews also covered the practitioners' work by asking questions such as 'Do you feel that the practitioner has control over the situation?' Data regarding success factors were collected through workshops with the practitioners, recalling the different projects and separating out success factors regarding the CITprocess's five steps.

The focus of the interviews was to identify success factors when the practitioners used the CIT-process and to identify potential problems related to group dynamics. The data were analyzed through thematic analysis, by clustering and identifying themes (Boyatzis, 1998) and charting these themes based on both the structure of the CIT-process and in the innovation process suggested by Tidd and Bessant (2013). Theories in the group dynamic process, as suggested by Wheelan (2013) were used to identify group-related problems.

\section{Findings}

The findings from this study are demonstrated in the following.

Table 1 Ensure management and sponsor commitment (CIT-process step 1)

\begin{tabular}{|l|l|l|l|l|}
\hline \multirow{2}{*}{ What } & \multicolumn{3}{|c|}{ Success factor by function } & Effect \\
\cline { 2 - 5 } & Management & Convener & Facilitator & \\
\hline Team A & - & $\begin{array}{l}\text { Based on trust by } \\
\text { management, the }\end{array}$ & $\begin{array}{l}\text { Quick, clear and } \\
\text { swift process }\end{array}$ \\
\hline $\begin{array}{l}\text { Management } \\
\text { and facilitator } \\
\text { had an }\end{array}$ & $\begin{array}{l}\text { Facilitator } \\
\text { provided }\end{array}$ & - &
\end{tabular}




\begin{tabular}{|c|c|c|c|c|}
\hline $\begin{array}{l}\text { established } \\
\text { relationship }\end{array}$ & $\begin{array}{l}\text { freedom based } \\
\text { on trust }\end{array}$ & & $\begin{array}{l}\text { facilitator could } \\
\text { work freely }\end{array}$ & \\
\hline $\begin{array}{l}\text { The problem } \\
\text { was well } \\
\text { known }\end{array}$ & $\begin{array}{l}\text { Management } \\
\text { provide a } \\
\text { clear task }\end{array}$ & $\begin{array}{l}\text { Confident } \\
\text { convener with } \\
\text { support from } \\
\text { management } \\
\text { and facilitator }\end{array}$ & - & $\begin{array}{l}\text { Quick, clear and } \\
\text { swift process }\end{array}$ \\
\hline $\begin{array}{l}\text { Manager/spon } \\
\text { sor had strong } \\
\text { and clear } \\
\text { position in the } \\
\text { organization }\end{array}$ & $\begin{array}{l}\text { Able to decide } \\
\text { and prioritize } \\
\text { the project }\end{array}$ & - & $\begin{array}{l}\text { Easy to plan for } \\
\text { preparation, } \\
\text { efficient work. }\end{array}$ & $\begin{array}{l}\text { Calm and } \\
\text { confident work }\end{array}$ \\
\hline \multicolumn{5}{|l|}{ Team B } \\
\hline- & - & - & - & - \\
\hline \multicolumn{5}{|l|}{ Team C } \\
\hline $\begin{array}{l}\text { Major } \\
\text { challenge to } \\
\text { work on. }\end{array}$ & $\begin{array}{l}\text { Decision to } \\
\text { initiate project } \\
\text { based on } \\
\text { identified } \\
\text { problem }\end{array}$ & - & - & $\begin{array}{l}\text { Identified } \\
\text { problems made } \\
\text { decision to start } \\
\text { easier }\end{array}$ \\
\hline $\begin{array}{l}\text { Resolve of } \\
\text { massive } \\
\text { resistance }\end{array}$ & $\begin{array}{l}\text { Powerful } \\
\text { internal work } \\
\text { to anchor } \\
\text { idea. }\end{array}$ & - & - & $\begin{array}{l}\text { Project definition } \\
\text { emerged }\end{array}$ \\
\hline $\begin{array}{l}\text { Support by } \\
\text { management }\end{array}$ & $\begin{array}{l}\text { Top } \\
\text { management } \\
\text { supported } \\
\text { work at all } \\
\text { times }\end{array}$ & $\begin{array}{l}\text { Calm and } \\
\text { confident in } \\
\text { work }\end{array}$ & $\begin{array}{l}\text { Calm and confident } \\
\text { in work }\end{array}$ & $\begin{array}{l}\text { Feeling of safe } \\
\text { work environment }\end{array}$ \\
\hline
\end{tabular}

Table 2 Identify convener (CIT-process step 2)

\begin{tabular}{|l|l|l|l|l|}
\hline \multirow{2}{*}{ What } & \multicolumn{3}{|c|}{ Success factor by function } & Effect \\
\cline { 2 - 5 } & Management & \multicolumn{1}{|c|}{ Convener } & Facilitator & \\
\hline Team A & $\begin{array}{l}\text { The sponsor } \\
\text { chose an }\end{array}$ & $\begin{array}{l}\text { Confident in } \\
\text { role as convener } \\
\text { with support }\end{array}$ & $\begin{array}{l}\text { Rapid process to } \\
\text { identify convener }\end{array}$ \\
\hline $\begin{array}{l}\text { Convener } \\
\text { identification }\end{array}$ & & & \\
\hline
\end{tabular}


This paper was presented at The ISPIM Innovation Conference - Innovating Our Common Future, Berlin, Germany on 7-10 June 2020.

Event Proceedings: LUT Scientific and Expertise Publications: ISBN 978-952-335-467-8

\begin{tabular}{|c|c|c|c|}
\hline & $\begin{array}{l}\text { appropriate } \\
\text { convener }\end{array}$ & $\begin{array}{l}\text { from } \\
\text { management } \\
\text { and facilitator. } \\
\text { Competence in } \\
\text { communication } \\
\text { and design }\end{array}$ & \\
\hline \multicolumn{4}{|l|}{ Team B } \\
\hline $\begin{array}{l}\text { Meeting to } \\
\text { focus on } \\
\text { project setting } \\
\text { and } \\
\text { participants }\end{array}$ & $\begin{array}{l}\text { Discussion on } \\
\text { projects } \\
\text { setting and } \\
\text { participants. }\end{array}$ & & $\begin{array}{l}\text { Holistic overview } \\
\text { of expectations } \\
\text { and a clear } \\
\text { deadline go/no go }\end{array}$ \\
\hline \multicolumn{4}{|l|}{ Team C } \\
\hline $\begin{array}{l}\text { Convener was } \\
\text { prepared for } \\
\text { project but not } \\
\text { about } \\
\text { facilitation }\end{array}$ & $\begin{array}{l}\text { Management } \\
\text { had pointed } \\
\text { out a suitable } \\
\text { candidate }\end{array}$ & $\begin{array}{l}\text { Instant project } \\
\text { accept }\end{array}$ & $\begin{array}{l}\text { Rapid start but } \\
\text { need of convener } \\
\text { preparation about } \\
\text { facilitator } \\
\text { function. }\end{array}$ \\
\hline $\begin{array}{l}\text { Support for } \\
\text { work by } \\
\text { management }\end{array}$ & $\begin{array}{l}\text { Top } \\
\text { management } \\
\text { supported } \\
\text { work at all } \\
\text { times }\end{array}$ & & $\begin{array}{l}\text { Feeling of safe } \\
\text { environment by } \\
\text { convener }\end{array}$ \\
\hline
\end{tabular}

Table 3 Introduce convener to process (CIT-process step 3)

\begin{tabular}{|c|c|c|c|c|}
\hline \multirow[t]{2}{*}{ What } & \multicolumn{3}{|c|}{ Success factor by function } & \multirow[t]{2}{*}{ Effect } \\
\hline & Management & Convener & Facilitator & \\
\hline \multicolumn{5}{|l|}{ Team A } \\
\hline $\begin{array}{l}\text { Meeting } \\
\text { facilitator and } \\
\text { convener one } \\
\text { on one. }\end{array}$ & & $\begin{array}{l}\text { Interested to } \\
\text { learn }\end{array}$ & & $\begin{array}{l}\text { Well organized } \\
\text { preparation. High } \\
\text { energy }\end{array}$ \\
\hline $\begin{array}{l}\text { The sponsor } \\
\text { chose a } \\
\text { competent } \\
\text { convener }\end{array}$ & & \multicolumn{2}{|c|}{$\begin{array}{l}\text { Good collaboration convener-facilitator. } \\
\text { Good interaction and easy to work } \\
\text { together, agile work by informal } \\
\text { meetings between team meetings. }\end{array}$} & $\begin{array}{l}\text { Rapid process. } \\
\text { Efficient work } \\
\text { due to the } \\
\text { convener's } \\
\text { competence in } \\
\text { communication } \\
\text { and design. }\end{array}$ \\
\hline \multicolumn{5}{|l|}{ Team B } \\
\hline $\begin{array}{l}\text { Meeting } \\
\text { facilitator and } \\
\text { conveners one } \\
\text { on one. }\end{array}$ & & $\begin{array}{l}\text { Individuals that } \\
\text { were interested } \\
\text { and wanted to } \\
\text { try. }\end{array}$ & & $\begin{array}{l}\text { Despite unclear } \\
\text { directions the } \\
\text { facilitators } \\
\text { accepted the role }\end{array}$ \\
\hline
\end{tabular}




\begin{tabular}{|l|l|l|l|l|}
\hline Team C & & $\begin{array}{l}\text { Open-minded } \\
\text { even though not } \\
\text { fully understood } \\
\text { the project and } \\
\text { methodology. }\end{array}$ & $\begin{array}{l}\text { Sent information } \\
\text { and explained at } \\
\text { meetings }\end{array}$ & $\begin{array}{l}\text { Quick } \\
\text { understanding }\end{array}$ \\
& & & & \\
\hline
\end{tabular}

Table 4 Gather team members (CIT-process step 4)

\begin{tabular}{|c|c|c|c|c|}
\hline \multirow[t]{2}{*}{ What } & \multicolumn{3}{|c|}{ Success factor by function } & \multirow[t]{2}{*}{ Effect } \\
\hline & Management & Convener & Facilitator & \\
\hline \multicolumn{5}{|l|}{ Team A } \\
\hline $\begin{array}{l}\text { Meeting } \\
\text { facilitator and } \\
\text { convener one } \\
\text { on one. }\end{array}$ & & $\begin{array}{l}\text { Interested to } \\
\text { learn }\end{array}$ & & $\begin{array}{l}\text { Well organized } \\
\text { preparation. High } \\
\text { energy }\end{array}$ \\
\hline $\begin{array}{l}\text { The sponsor } \\
\text { chose a } \\
\text { competent } \\
\text { convener }\end{array}$ & & \multicolumn{2}{|c|}{$\begin{array}{l}\text { Good collaboration convener- } \\
\text { facilitator. Good interaction and easy to } \\
\text { work together, agile work by informal } \\
\text { meetings between team meetings. }\end{array}$} & $\begin{array}{l}\text { Rapid process. } \\
\text { Efficient work } \\
\text { due to the } \\
\text { convener's } \\
\text { competence in } \\
\text { communication } \\
\text { and design. }\end{array}$ \\
\hline \multicolumn{5}{|l|}{ Team B } \\
\hline $\begin{array}{l}\text { Meeting } \\
\text { facilitator and } \\
\text { conveners one } \\
\text { on one. }\end{array}$ & & $\begin{array}{l}\text { Individuals that } \\
\text { were interested } \\
\text { and wanted to } \\
\text { try. }\end{array}$ & & $\begin{array}{l}\text { Despite unclear } \\
\text { directions the } \\
\text { facilitators } \\
\text { accepted the role }\end{array}$ \\
\hline \multicolumn{5}{|l|}{ Team C } \\
\hline
\end{tabular}


This paper was presented at The ISPIM Innovation Conference - Innovating Our Common Future, Berlin, Germany on 7-10 June 2020.

Event Proceedings: LUT Scientific and Expertise Publications: ISBN 978-952-335-467-8

\begin{tabular}{|l|l|l|l|l|}
\hline Mind-set & $\begin{array}{l}\text { Open-minded } \\
\text { even though not } \\
\text { fully understood } \\
\text { the project and } \\
\text { methodology. }\end{array}$ & $\begin{array}{l}\text { Sent information } \\
\text { and explained at } \\
\text { meetings }\end{array}$ & $\begin{array}{l}\text { Quick } \\
\text { understanding }\end{array}$ \\
& & & & \\
\hline
\end{tabular}

Table 5 Kick off project (CIT-process step 5)

\begin{tabular}{|c|c|c|c|c|c|}
\hline \multirow[t]{2}{*}{ What } & \multicolumn{4}{|c|}{ Success factor by function } & \multirow[t]{2}{*}{ Effect } \\
\hline & Management & Convener & Facilitator & Team & \\
\hline \multicolumn{6}{|l|}{ Team A } \\
\hline $\begin{array}{l}\text { Good plan for } \\
\text { kick-off }\end{array}$ & & & $\begin{array}{l}\text { Trusted } \\
\text { the } \\
\text { process }\end{array}$ & & Good start \\
\hline $\begin{array}{l}\text { Established } \\
\text { norms }\end{array}$ & & & & $\begin{array}{l}\text { Good } \\
\text { discussions. }\end{array}$ & Loyal to project \\
\hline $\begin{array}{l}\text { Worked on } \\
\text { task }\end{array}$ & & & & $\begin{array}{l}\text { Buy-in, } \\
\text { questioned } \\
\text { and } \\
\text { modified }\end{array}$ & $\begin{array}{l}\text { Motivation and } \\
\text { more specific } \\
\text { task. Team } \\
\text { understood the } \\
\text { task but also } \\
\text { modify and } \\
\text { further develop } \\
\text { task in a good } \\
\text { way }\end{array}$ \\
\hline \multicolumn{6}{|l|}{ Team B } \\
\hline $\begin{array}{l}\text { Good kick-off } \\
\text { with two } \\
\text { teams with } \\
\text { two conveners }\end{array}$ & & & & $\begin{array}{l}\text { High level } \\
\text { of } \\
\text { motivation. } \\
\text { Interesting } \\
\text { discussions } \\
\text { on task. }\end{array}$ & \\
\hline
\end{tabular}




\begin{tabular}{|c|c|c|c|c|}
\hline $\begin{array}{l}\text { Recruitment } \\
\text { of members } \\
\text { that want to } \\
\text { contribute. }\end{array}$ & & & & $\begin{array}{l}\text { Right people can } \\
\text { do almost } \\
\text { anything. }\end{array}$ \\
\hline \multicolumn{5}{|l|}{ Team C } \\
\hline $\begin{array}{l}\text { Clear } \\
\text { facilitation }\end{array}$ & & $\begin{array}{l}\text { Clear and } \\
\text { concise } \\
\text { communic } \\
\text { ation }\end{array}$ & & $\begin{array}{l}\text { Team members } \\
\text { quickly realized } \\
\text { the basic } \\
\text { conditions in the } \\
\text { process, which } \\
\text { enabled a good } \\
\text { continuation }\end{array}$ \\
\hline $\begin{array}{l}\text { Management } \\
\text { Support }\end{array}$ & $\begin{array}{l}\text { Top } \\
\text { management } \\
\text { supported } \\
\text { work at all } \\
\text { times }\end{array}$ & & $\begin{array}{l}\text { Feeling of } \\
\text { safe } \\
\text { environment }\end{array}$ & - \\
\hline $\begin{array}{l}\text { Tools for } \\
\text { getting to } \\
\text { know each } \\
\text { other }\end{array}$ & & & & $\begin{array}{l}\text { Team members } \\
\text { got to know each } \\
\text { other. }\end{array}$ \\
\hline
\end{tabular}

Table 6 Quotes regarding success factors in the CIT-process

\begin{tabular}{|l|l|}
\hline \multicolumn{1}{|c|}{ Role } & \multicolumn{1}{c|}{ Quote related to success factors } \\
\hline Manager & $\begin{array}{l}\text { [... a general reflection is that is has been very fun to try this way of working. It } \\
\text { seems obviously working. In the calendar, the work is spread out, but in terms } \\
\text { of investment it is actually very small for how much you get out of it] }\end{array}$ \\
\hline Sponsor & $\begin{array}{l}\text { [...I think it's fundamental...I think (the facilitator) has the experience to } \\
\text { actually foresee how the team is going to behave, how they going to react. And } \\
\text { I think it's very good that, (the facilitator) has been working with companies } \\
\text { before and (the facilitator) knows what to expect and (the facilitator) knows } \\
\text { how to counter attack somehow. I mean, all of the team members are very } \\
\text { result oriented, like engineers work every day delivering, delivering, } \\
\text { delivering. Of course, giving them this fluffy task is very hard for them, so, I } \\
\text { think (the facilitator) is great at not only explaining the methodology, leading } \\
\text { the team through the different activities, but I think that it's very good that } \\
\text { also knowing when to stop them ... I think, eeah, (the facilitator) knows to } \\
\text { handle the team ... without not causing any disturbance or anything so (the } \\
\text { facilitator) just smoothly leads them to something else...So, I think (the } \\
\text { facilitator) is pretty good at that.] }\end{array}$ \\
\hline Sponsor & $\begin{array}{l}\text { [...Well. We would never have been able to do this ourselves, for sure. After } \\
\text { all, we need the innovation coach, or (referring to the facilitator) in this case. }\end{array}$ \\
\hline
\end{tabular}


This paper was presented at The ISPIM Innovation Conference - Innovating Our Common Future, Berlin, Germany on 7-10 June 2020.

Event Proceedings: LUT Scientific and Expertise Publications: ISBN 978-952-335-467-8

\begin{tabular}{|c|c|}
\hline & $\begin{array}{l}\text { It is a success factor. I think, even though we had received a book on how it } \\
\text { (referring to the CIT-process) works, I do not think we could have succeeded } \\
\text { without having that support. In general, I think the way of working has been } \\
\text { good. Because you take the time to set things properly and document it, you } \\
\text { can put it aside and move on, focusing on what you have agreed upon ...] }\end{array}$ \\
\hline $\begin{array}{l}\text { Team } \\
\text { member }\end{array}$ & $\begin{array}{l}\text { II think we are all curious. We want something. We are here of our own free } \\
\text { will... I think it's great that we have (referring to the facilitator). Someone } \\
\text { (referring to the facilitator) who can hold us in the hand and guide us to } \\
\text { what we really should do. Otherwise, we just get stuck, or we don't really } \\
\text { know what to do. ] }\end{array}$ \\
\hline $\begin{array}{l}\text { Team } \\
\text { member }\end{array}$ & $\begin{array}{l}\text { [I think we are quite similar in the group as individuals. It is not a group of } \\
\text { five completely different individuals but five individuals who are fairly } \\
\text { similar and have about the same background or similar background.] }\end{array}$ \\
\hline $\begin{array}{l}\text { Team } \\
\text { member }\end{array}$ & $\begin{array}{l}\text { [...we have very diverse backgrounds, different ways of thinking about } \\
\text { things, and everyone's mind is allowed to take up space ... I think that works } \\
\text { great because you get the chance to drift away sometimes, and if you go too } \\
\text { far away, you will be nudged back on track (by the facilitator). But it's really } \\
\text { not are stuck on a straight track; there is space to explore, but you will always } \\
\text { go forward.] }\end{array}$ \\
\hline $\begin{array}{l}\text { Team } \\
\text { member }\end{array}$ & $\begin{array}{l}\text { [I think it's great that we have diverse professions and different } \\
\text { personalities.] }\end{array}$ \\
\hline $\begin{array}{l}\text { Team } \\
\text { member }\end{array}$ & $\begin{array}{l}\text { [One success factor is that we have different backgrounds and that we are in } \\
\text { different places in this large organization. In my daily work, I have a holistic } \\
\text { position; another member is working in a completely different department. } \\
\text { [name 1] works close to the users at the operational level, and [name 2] has a } \\
\text { completely different role.] }\end{array}$ \\
\hline Team C & $\begin{array}{l}\text { [... This team is a success factor ... when one of us had an obstacle, you } \\
\text { were not replaced by someone else. I think this is a success factor, because } \\
\text { then you feel safe on this team. You do not have to start with new views. We } \\
\text { are a strong team that meet regularly, which is great]... [... It is also good } \\
\text { with obvious things as setting up rules to respect each other's points of view } \\
\text { and respect each other's competence. Unfortunately, we have too often been } \\
\text { told what to say, what can or cannot be, but here, all that was taboo. And if } \\
\text { anyone ever came near that way of acting, the facilitator stopped it } \\
\text { immediately, which was great. Of course, these things are obvious, but it is } \\
\text { not so in reality always. So, I think it is a success factor.]... [Perhaps this } \\
\text { was possible because someone was regulating it from the start. Here, the } \\
\text { facilitator has from the beginning been talking about and making us set } \\
\text { rules. It was a quite soft start but very clear focus on the rules. It is like } \\
\text { kindergarten really, but sometimes it is needed.] ... [...We are all here for a } \\
\text { reason. Everyone is here because of the person's competence.]. }\end{array}$ \\
\hline
\end{tabular}

Three main themes appeared as key success factors: knowledge adoption, knowledge transition and knowledge transfer. 
The participants' ability to adopt new knowledge (knowledge adoption) and convert it into action (knowledge transition) was identified throughout the use of the CIT-process at all levels in the organizations, starting both with the practitioners advising management and sponsors providing distinct directions for the innovation projects and supporting the innovation teams' ongoing work. With clear directions, the conveners in Team A and Team $C$ managed to attract team members with suitable competences, and with the support of the practitioners, they established the innovation teams. On Team B, however, management caused significant problems by ignoring the practitioners' advice, for example, by inviting twice as many team members as recommended to the kick-off and not informing the practitioners about it. However, at the kick-off, the practitioners split Team B into two sub-innovation teams (Team B1 and Team B2), and these new teams were then successfully established, but the process was not as effective as the other teams.

Knowledge transfer was observed through the practitioners' facilitating skills, as they educated and advised all participants on the go, depending on the situation. Important to highlight is that the innovation teams operated in different business areas. The practitioners, however, managed to adjust their advice according to situation.

None of the innovation teams, despite the problems creating Team B, indicated group dynamic problems. However, Team A and Team $\mathrm{C}$ emerged faster than the other innovation teams.

\section{Contribution}

In this research, practitioners were participating in the role of innovation facilitators. Literature on innovation facilitators within the field of innovation management indicates that this is an important role supporting innovation within organizations. This study contributes to prior research by indicating that innovation facilitators also spur the creation of innovation teams. Additionally, the study contributes to knowledge of the CIT-process by indicating that this process supports the creation of innovation teams if conducted as suggested and if the participating individuals have the ability to adopt new knowledge.

\section{Practical implications and future work}

The practical implications from this research mainly concern the implementation of the CIT-process. For example, innovation leaders may benefit from the results when implementing the CIT-process in their own organization, and consultants may use the results when advising or educating clients in the use of the CIT-process. Given the limited number of participating organizations in this research, further studies on the implementation of the CIT-process are suggested to increase understanding and to develop educational tools. 
This paper was presented at The ISPIM Innovation Conference - Innovating Our Common Future, Berlin, Germany on 7-10 June 2020.

Event Proceedings: LUT Scientific and Expertise Publications: ISBN 978-952-335-467-8

\section{References}

Boyatzis, R. E. (1998). Transforming Qualitative Information: Thematic analysis and code development. SAGE Publications Inc, USA.

Chen, J., Damanpour, F. \& Reilly, R. R. (2010). Understanding antecedents of new product development speed: A meta-analysis. Journal of Operational Management, Vol 28, pp. 17-33.

Farris, G. F. (1972). The effect of individual roles on performance in innovative groups. $R \& D$ Management, 3(1), 23-28.

Kesting, P. \& Ulhöj J. P. (2010). Employee-driven innovation: extending the license to foster innovation. Management Decision, 48(1), 65-84.

Kristiansen, M., \& Bloch-Poulsen, J. (2010). Employee Driven Innovation in Team (EDIT) - Innovative Potential, Dialogue. International Journal of Action Research, 6(2-3), 155-195.

Highsmith, J. (2009). Agile Project Management: Creating Innovative Products. Crawfordsville: Addison-Wesley.

Im, S., Montoya, M. M., \& Workman, J. P. (2013). Antecedents and consequences of creativity in product innovation teams. Journal of Product Innovation Management, 30(1), 170-185.

Johnsson, M. (2016a). Important innovation enablers for innovation teams. In The XXVII Innovation Conference - Blending Tomorrow's Innovation Vintage, Porto, Portugal.

Johnsson, M. (2016b). The importance of innovation enablers for innovation teams. In The $23^{r d}$ EurOMA Conference, Trondheim, Norway, June 2016.

Johnsson, M. (2017a). Innovation Enablers for Innovation Teams - A Review. Journal of Innovation Management, 5(3), 75-121.

Johnsson, M. (2017b). Creating High-performing Innovation Teams. Journal of Innovation Management, 5(4), 23-47.

Johnsson, M. (2018). The Facilitator, its characteristics and importance for innovation teams. Journal of Innovation Management, 6(2), 12-44.

Johnsson, M., Swenningsson, K., \& Svensson, E. (2019). Problems when implementing innovation teams. In The XXX Innovation Conference - Celebrating Innovation: 500 Years Since DaVinci, Florens, Italy, 16-19 June 2019.

McDonough III, E.F. (2000). Investigation of Factors Contributing to the Success of Cross-Functional Teams. Journal of Product Innovation Management, 17(3), 221235.

McGreevy, M. (2006). Team working: part 2 - how are teams chosen and developed, Industrial and commercial training, 38(7), 365-370.

Neuman, G. A., Wagner, S. H., \& Christiansen, N. D. (1999). The relationship between work team personality composition and the job performance of teams, Group \& Organization Management, 24(1), 28-45.

Pearce, C. L., \& Ensley, M. D. (2004). A reciprocal and longitudinal investigation of the innovation process: The central role of shared vision in product and process innovation teams (PPITs). Journal of Organizational Behavior, 25(2), 259-278.

Tidd, J. \& Bessant, J. (2013). Managing Innovation - Integrating Technological, Market and Organizational Change, fifth edition. West Sussex, John Wiley \& Sons Ltd. 
West, M., Hirst, G., Richter, A. and Shipton, H. (2004). “Twelve steps to heaven: Successfully managing change through developing innovative teams", European Journal of Work and Organizational Psychology, Vol 13, No. 2, pp. 269-299.

Wheelan, S. A. (2013), Creating Effective Teams - A Guide for Members and Leaders. Studentlitteratur AB, Lund.

Zuidema, K.R., \& Kleiner, B.H. (1994). Self-directed work groups gain popularity. Business Credit, 96(9), 21-26. 